\title{
Comparison of the Effects of VIP and PACAP on Steroid Secretion of Dispersed Rat Adrenocortical Cells
}

\author{
Krzysztof W. Nowak ${ }^{1}$, Giuliano Neri ${ }^{2}$, Gastone G. Nussdorfer ${ }^{2}$ and Ludwik K. Malendowicz ${ }^{3}$ \\ ${ }^{1}$ Department of Animal Physiology and Biochemistry, Poznan University of Agriculture, Poznan, Poland; ${ }^{2}$ Department of Human \\ Anatomy and Physiology, Section of Anatomy, University of Padua, Padua, Italy; and ${ }^{3}$ Department of Histology and Embryol- \\ ogy, School of Medicine, Poznan, Poland
}

(Received 10 March 1999; and accepted 22 April 1999)

\begin{abstract}
The effects of vasoactive intestinal peptide (VIP) and pituitary adenylate cyclase-activating polypeptide (PACAP)-38 or -27, and their receptor antagonists (VIP-A, P38-A and P27-A) have been investigated on aldosterone and corticosterone secretion in dispersed rat zona glomerulosa $(\mathrm{ZG})$ and zona fasciculata-reticularis $(\mathrm{ZF} / \mathrm{R})$ cells. VIP and PACAP-38 enhanced both aldosterone and corticosterone production, VIP being much more effective than PACAP-38. PACAP-27 elicited only a moderate increase in corticosterone production. The ACTH receptor antagonist corticotropin-inhibiting peptide and the $\beta$-adrenoceptor antagonist $l$-alprenolol did not affect hormonal response to the maximal effective concentration $\left(10^{-6}\right.$ $\mathrm{M}$ ) of VIP and PACAPs. VIP-A, which is an antagonist of VPACl receptor subtype, counteracted only corticosterone response to PACAP-38. P38-A, which is an antagonist of $\mathrm{PAC} 1$ receptor and VPAC2 receptor subtypes, hampered aldosterone response to VIP and PACAP-38, and corticosterone response to VIP and PACAP-27. P27-A, whose receptor selectivity is not known. VIP-A potentiated corticosterone response to VIP, and aldosterone response to PACAP-38. These findings led us to conclude: (i) VIP and PACAPs stimulate secretion of rat adrenocortical cells, through the activation of specific receptors, being their effectiveness VIP $>$ PACAP-38 > > PACAP-27; and (ii) aldosterone response of ZG cells to VIP and PACAPs is probably mediated by $\mathrm{PAC}_{1}$ and $\mathrm{VPAC}_{2}$ receptors, while corticosterone response of $\mathrm{ZF} / \mathrm{R}$ cells involves also the $\mathrm{VPAC}_{1}$ receptor subtype.
\end{abstract}

Vasoactive intestinal peptide (VIP) is a highly basic 28-amino acid peptide, and pituitary adenylate cyclase-activating polypeptide (PACAP) is a basic 38-amino acid C-terminally (-amidated peptide, which were originally isolated from the gastrointestinal tract and hypothalamus, respectively. An alternative form of PACAP possessing the $\mathrm{N}$-terminal 27-amino acid sequence of PACAP-38 was also isolated from

Correspondence to: Dr Nussdorfer at the above address.

Tel: (+39) 049827 2317; Fax: (+39) 049827 2319; E-mail: ggnanat@ipdunidx.unipd.it hypothalamic extracts, and named PACAP-27 (for review, see 3, 24). VIP and PACAP possess a remarkable amino-acid sequence homology, and act through common G protein-coupled VIP/ $\mathrm{PACAP}$ receptors, three main subtypes of which are presently recognized and called $\mathrm{PAC}_{1}, \mathrm{VPAC}_{1}$ and $\mathrm{VPAC}_{2}$ (for review, see 10 ).

Several investigations demonstrated the presence of a pleiad of biologically active peptides in the mammalian adrenal gland, which are localized in the medullary chromaffin cells, in the intrinsic ganglion neurons and/or in the nerve fibers of different origin. Nussdorfer (23) reviewed evidence that these peptides may affect 
adrenocortical growth and secretion, acting in a paracrine manner. VIP and PACAP belong to this group of regulatory peptides: they are contained in sizeable amounts in adrenals, adrenals are provided with VIP/PACAP binding sites, and the two peptides variously affect the in vitro secretory activity of adrenocortical cells (for review, see 24).

However, conflicting data are available on the direct effect of VIP and PACAP on mineraloand glucocorticoid secretion. Therefore, the aim of this study was to compare the effects of the two peptides on aldosterone and corticosterone production of dispersed rat zona glomerulosa ( $Z G)$ and zona fasciculata-reticularis $(\mathrm{ZF} / \mathrm{R})$ cells, and to characterize the subtype(s) of VIP/PACAP receptors involved.

\section{MATERIALS AND METHODS}

VIP, PACAP-38, PACAP-27, the VIP antagonist (VIP-A) [Ac-Tyr ${ }^{1}$, D-Phe $\left.{ }^{2}\right]$-GRF (1-29) amide (29), the PACAP-38 antagonist (P38-A) PACAP $(6-38)(26)$, and the PACAP-27 antagonist (P27-A) PACAP $(6-27)(2)$ were obtained from Bachem (Bubendorf, Switzerland). ACTH $(1-24)$, the ACTH-receptor antagonist corticotropin inhibiting peptide (CIP) (13), the $\beta$-adrenoceptor antagonist $l$-alprenolol (15), and other laboratory reagents were purchased from Sigma Chem. Co. (St. Louis, MO, U.S.A.).

Adrenal glands, obtained from adult female Wistar rats, were gently decapsulated to separate $Z G$ from $Z F / R$, and dispersed capsular $(Z G)$ and inner $(\mathrm{ZF} / \mathrm{R})$ adrenocortical cells were obtained by collagenase digestion and mechanical disaggregation (12). Inner cell contamination of capsular-cell preparations, and the viability of dispersed cells were checked as previously detailed (17), and found to be less than $8 \%$ and higher than 92\%, respectively. Dispersed cells obtained from 6-8 rats were pooled to obtain a single cell suspension, and six cell suspensions for each incubation experiment were employed.

Aliquots of each cell suspension $\left(10^{-5}\right.$ cells $/ \mathrm{mL}$ in Krebs-Ringer bicarbonate buffer with $0.3 \%$ glucose and $0.2 \%$ bovine serum albumin) were incubated as follows: (i) VIP, PACAP-38 or PACAP-27 (from $10^{-12}$ to $10^{-6} \mathrm{M}$ ) alone or in the presence of $10^{-9} \mathrm{M}$ ACTH(1-24); (ii) VIP, PACAP-38 or PACAP-27 $\left(10^{-6} \mathrm{M}\right)$ in the presence or absence of $10^{-5} \mathrm{M}$ VIP-A, P38-A or $\mathrm{P} 27-\mathrm{A}$, and (ii) CIP or $l$-alprenolol $\left(10^{-6} \mathrm{M}\right)$ alone or in the presence of $10^{-6} \mathrm{M}$ VIP, PACAP38 or PACAP-27. The incubation was carried out in a shaking bath at $37^{\circ} \mathrm{C}$ for $60 \mathrm{~min}$, in an atmosphere of $95 \%$ air $-5 \% \mathrm{CO}_{2}$. At the end of the experiments, the incubation tubes were centrifuged at $4^{\circ} \mathrm{C}$, and supernatants stored at $-30^{\circ} \mathrm{C}$.

Aldosterone and corticosterone were extracted from incubation media and purified by HPLC (22), and their concentrations estimated by specific RIA, as previously detailed (16). Intra- and interassay variation coefficients were: aldosterone, $5 \%$ and $7 \%$; and corticosterone, $7 \%$ and $9 \%$, respectively.

Data were expressed as means \pm SEM, and their statistical comparison was done by ANOVA, followed by the multiple range test of Duncan.

\section{RESULTS AND DISCUSSION}

VIP concentration-dependently increased basal aldosterone and corticosterone secretion by dispersed $Z G$ and $Z F / R$ cells, respectively, maximal effective concentration being $10^{-6} \mathrm{M}$. Likewise, PACAP-38 enhanced basal production of the two hormones, but the effect became significant only at a concentration of $10^{-6} \mathrm{M}$. PACAP27 did not affect basal secretion of aldosterone, but at a concentration of $10^{-6} \mathrm{M}$ evoked a moderate rise in that of corticosterone (Fig. 1). ACTHstimulated steroid secretion was not affected by the three peptides (data not shown).

Contrasting findings are available as to the direct effects of VIP and PACAP on mammalian adrenocortical cells. To summarize, Hinson et al. $(11,12)$ did not observe any effect of VIP on dispersed rat adrenocortical cells, while Mazzocchi et al. (18) reported a clear-cut secretagogue action. VIP was found to stimulate cortisol production by dispersed bovine adrenocortical cells (14), but not aldosterone secretion of cultured calf ZG cells (6). This peptide also elicited a marked secretagogue action on both cultured human adrenocortical cells (7) and human adrenocortical carcinoma cell line NCI-H295 (6, 9). PACAP-38 did not affect secretion of dispersed rat and human adrenocortical cells $(1,21)$, but both PACAP-38 and PACAP-27 were reported to raise aldosterone secretion (and cyclic-AMP release) by bovine cultured ZG cells (6). Our present study provides evidence that VIP and PACAP are able to directly stimulate the secre- 

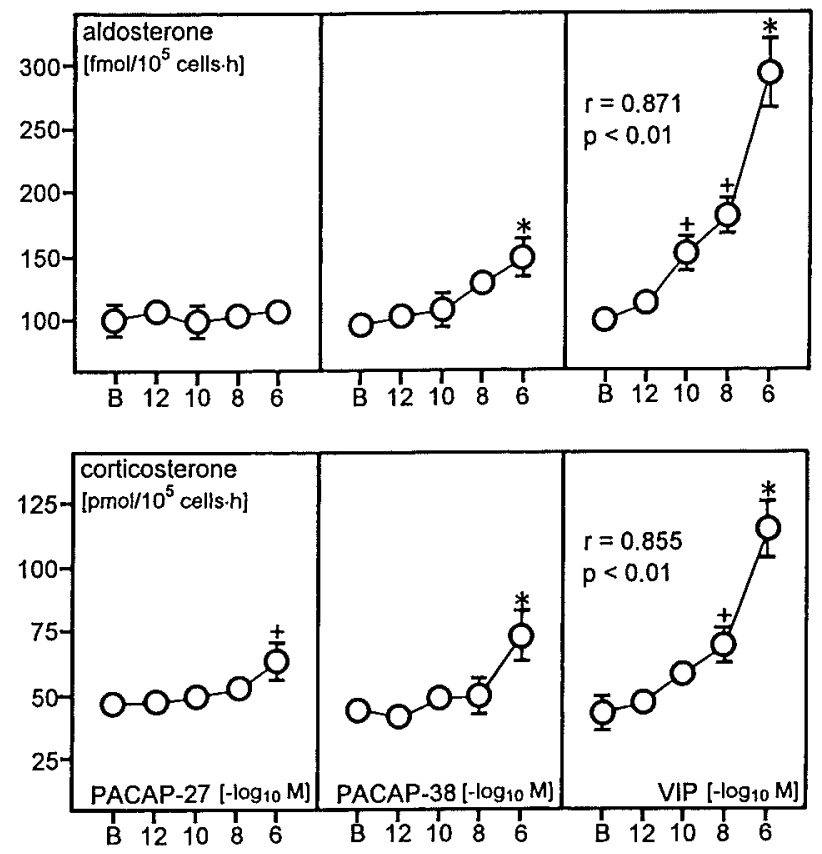

Fig. 1 Effects of PACAPs and VIP on aldosterone (upper panels) and corticosterone secretion (lower panels) of dispersed rat $\mathrm{ZG}$ and $\mathrm{ZF} / \mathrm{R}$ cells, respectively. Data are means \pm SEM $(\mathrm{n}=6) .{ }^{+} P<0.05$ and $* P<0.01$ from baseline value $(\mathrm{B})$.

tory activity of both $\mathrm{ZG}$ and $\mathrm{ZF} / \mathrm{R}$ cells of the rat adrenals, their effectiveness being VIP $>$ PACAP$38>>$ PACAP-27. According to Arimura et al. (4), the concentration of PACAP-27 in the rat adrenal is about 70 -fold less than that of PACAP-38, and our results are in keeping with the minor role played by PACAP-27 in the tuning of rat adrenal secretory activity.

CIP significantly increased basal secretion of aldosterone, and this effect manifested itself even in the presence of VIP and PACAPs. This result accords well with the view that CIP is able to stimulate ZG cells through a mechanism involving the activation of angiotensin-II receptors and the consequent rise in the cytosolic $\mathrm{Ca}^{2+}$ concentration (17). Conversely, CIP did not alter either basal or VIP- and PACAP-stimulated corticosterone production. l-Alprenolol was ineffective (Fig. 2).

These findings are relevant because they rule out the possibility that VIP and PACAPs act by activating $\mathrm{ACTH}$ receptors and $\beta$-adrenoceptors located on adrenocortical cells. This possibility stems from the observations that (i) VIP, GH-RH and dynorphin compete for a common subtype of
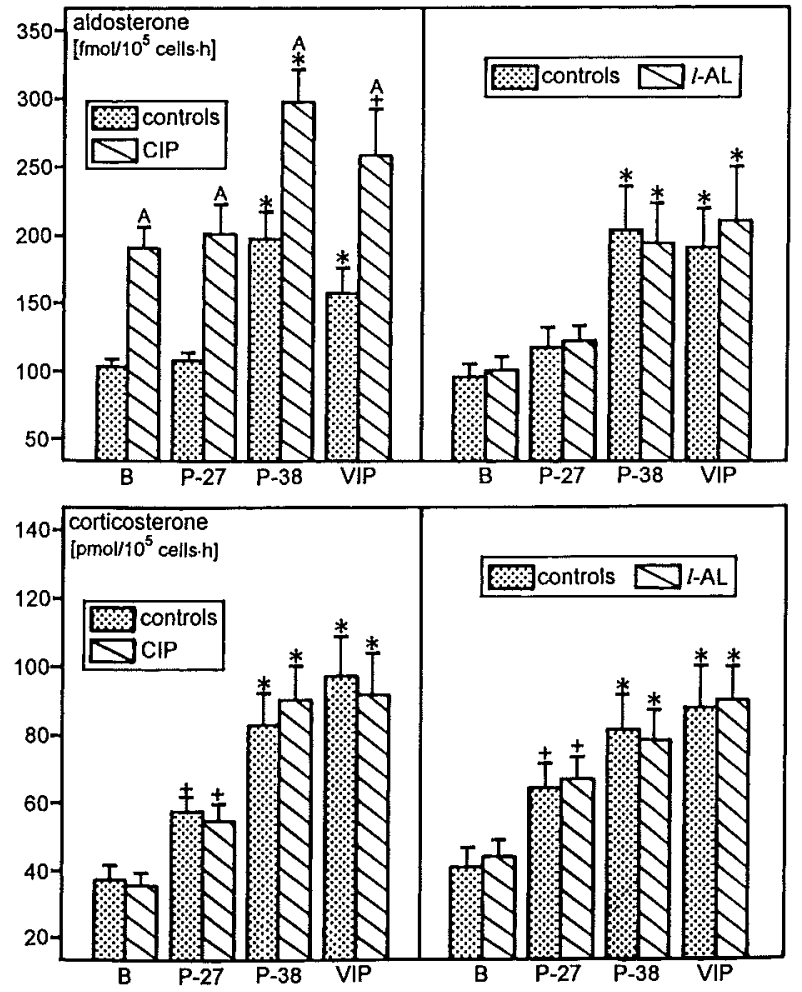

Fig. 2 Effects of CIP $\left(10^{-6} \mathrm{M}\right)$ and $l$-alprenolol $\left(l-\mathrm{AL}, 10^{-6} \mathrm{M}\right)$ on basal and PACAP-38 (P-38), PACAP-27 (P-27) or VIP ( $\left.10^{-6} \mathrm{M}\right)$-stimulated aldosterone (upper panels) and corticosterone secretion (lower panels) of dispersed rat $\mathrm{ZG}$ and $\mathrm{ZF} / \mathrm{R}$ cells, respectively. Bars are means $\pm \operatorname{SEM}(n=6)$. ${ }^{\mathrm{A}} P<0.01$ from the respective control value; ${ }^{+} P<0.05$ and ${ }^{*} P<0.01$ from the respective baseline value (B).

ACTH receptors in brain and adrenals (14), and CIP impairs in vitro glucocorticoid secretagogue effect of VIP and PACAP $(1,19,20)$; and (ii) the $\beta$-adrenoceptor antagonists, like $l$-alprenolol or atenolol, counteract aldosterone secretagogue effect of VIP $(5,12,18)$ and PACAP-38 (1). Since these last in vitro results were obtained using capsular-adrenal or adrenal-slice preparations, our present observations support the view that VIP and PACAP may indirectly affect aldosterone secretion by eliciting the release of catecholamines, which in turn activate $\beta$ adrenoceptor located on $Z G$ cells in a paracrine manner (for review, see 23).

The effects of VIP/PACAP-receptor antagonists, alone or combined with maximal effective concentrations of VIP, PACAP-38 or PACAP-27 are depicted in Figs. 3 and 4. To summarize: none 
of the antagonists altered per se basal secretion of dispersed rat adrenocortical cells, with the exception of P38-A, which evoked a moderate lowering in aldosterone production. The aldosterone and corticosterone responses to VIP were decreased by $\mathrm{P} 38-\mathrm{A}$, and corticosterone response was enhanced by both VIP-A and P27-A. Aldosterone response to PACAP-38 was suppressed by P38-A and potentiated by VIP-A, which on the contrary partially reduced corticosterone response. As expected, PACAP-27 did not affect aldosterone production, but in the presence of VIP-A a slight rise was found. Corticosterone response to PACAP-27 was abolished by P38-A and unaffected by other antagonists.
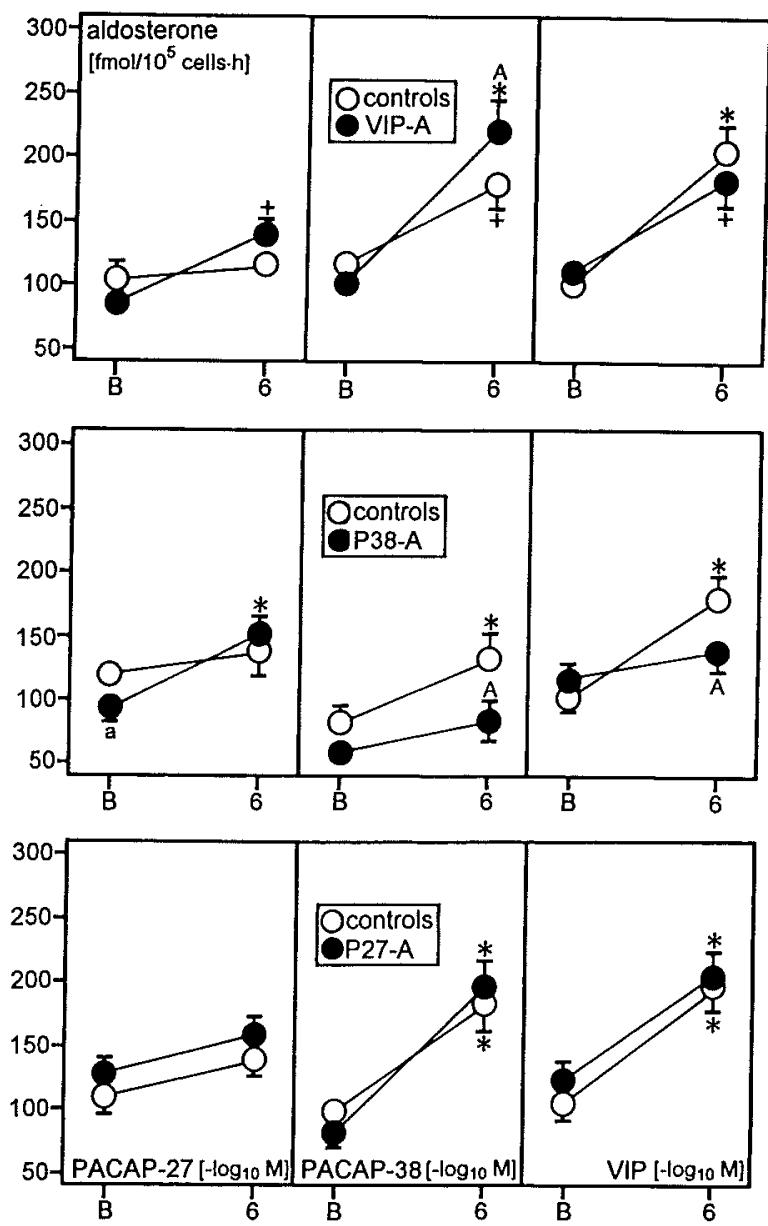

Fig. 3 Effect of VIP and PACAP antagonists $\left(10^{-5}\right.$ M) on basal and VIP-, PACAP-38-or PACAP-27stimulated aldosterone secretion of dispersed rat $Z G$ cells. Data are means \pm SEM $(\mathrm{n}=6) .{ }^{+} P<0.05$ and ${ }^{*} P<0.01$ from the respective baseline value (B); ${ }^{\text {a }} P<0.05$ and ${ }^{\mathrm{A}} P<0.01$ from the respective control value.
As mentioned in the Introduction, VIP and PACAPs act through at least three subtypes of receptors, whose binding potency is as follows: PAC $1, \quad$ PACAP-38 $=$ PACAP-27>>VIP $\mathrm{VPAC} 1, \quad \mathrm{VIP}=\mathrm{PACAP}-27>\mathrm{PACAP}-38 ;$ and $\mathrm{VPAC} 2, \mathrm{VIP}=\mathrm{PACAP}-38=\mathrm{PACAP}-27 . \mathrm{VIP}-\mathrm{A}$ and $\mathrm{P} 38-\mathrm{A}$ are antagonists of $\mathrm{VPAC} 1$ and $\mathrm{PACl}$ receptors, while selective VPAC2-receptor antagonists are not known at present (for review, see $10,24,25)$. However, PACAP $(6-38)$, i.e. P38-A, has been show to possess also high affinity for $\mathrm{VPAC}_{2}$ receptors (8).

In light of these considerations, our results allow us to draw the following conclusions. VIP and PACAP-38 stimulate aldosterone secretion
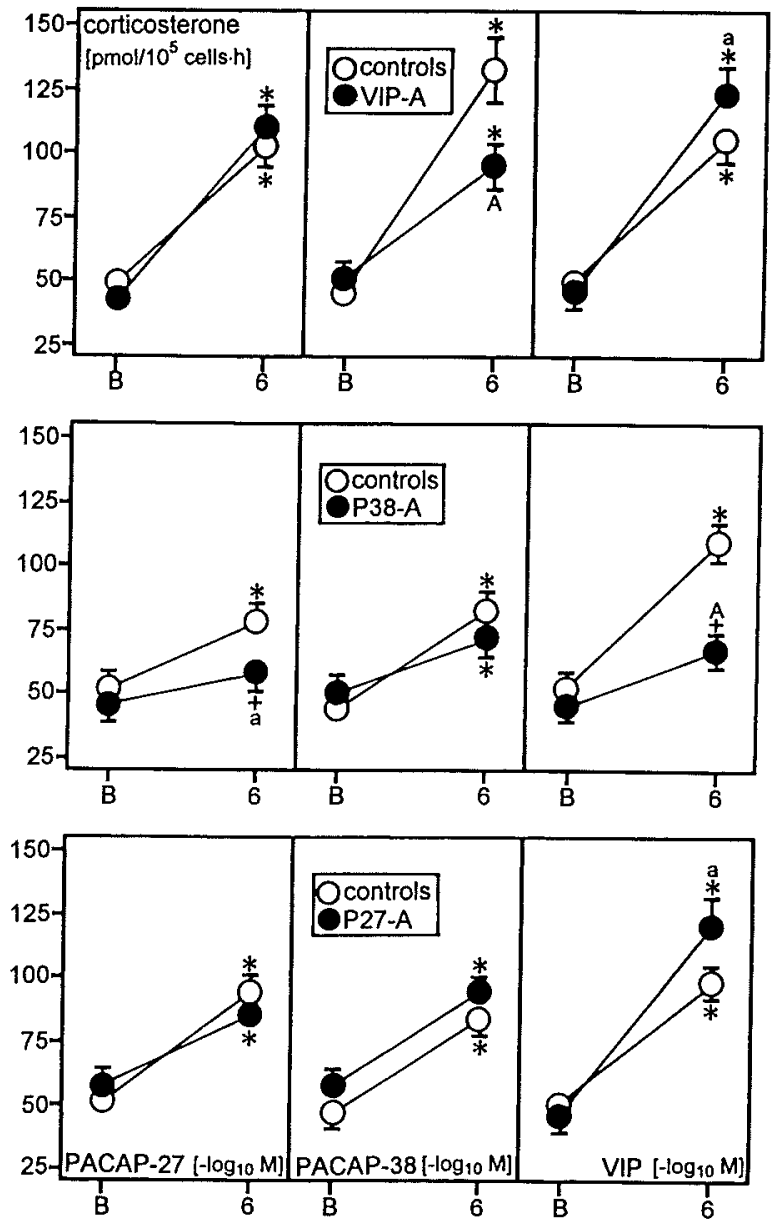

Fig. 4 Effect of VIP and PACAP antagonists $\left(10^{-5}\right.$ $\mathrm{M})$ on basal and VIP-, PACAP-38-or PACAP-27stimulated corticosterone secretion of dispersed rat $\mathrm{ZF} / \mathrm{R}$ cells. Data are means \pm SEM $(\mathrm{n}=6){ }^{+} P<0.05$ and ${ }^{*} P<0.01$ from the respective baseline value (B); ${ }^{a} P<0.05$ and ${ }^{\mathrm{A}} P<0.01$ from the respective control value. 
acting through $\mathrm{PAC}_{1}$ and perhaps $V P A C_{2}$ receptors, since their effect is blocked only by PACAP $(6-38)$. The potentiation of PACAP-38 effect by VIP-A can be consequent to a higher availability of PACAP to $\mathrm{PAC}_{1}$ and $\mathrm{VPAC}_{2}$ receptors due to the occupancy of $\mathrm{VPAC}_{1}$ by the antagonist, and the same mechanism could explain the moderate aldosterone secretagogue of PACAP-27 in the presence of VIP-A. VIP enhances corticosterone secretion by activating $\mathrm{PAC}_{1}$ and perhaps $V P A C_{2}$ receptors, because its effect is exclusively counteracted by P38-A and potentiated by VIP-A and P27-A, and the same holds true for PACAP-27. In contrast, the corticosterone secretagogue action of PACAP-38 appears to be exclusively mediated by $\mathrm{VPAC}_{1}$ receptors, inasmuch as it is exclusively counteracted by VIP-A. Collectively, these findings suggest that while rat $Z G$ cells are almost exclusively provided with $\mathrm{PAC}_{1}$ and $\mathrm{VPAC} \mathrm{C}_{2}$ receptors, $\mathrm{ZF} / \mathrm{R}$ cells possess all three subtypes of receptors.

Obviously, our study leaves unsettled many issues, among which are the following. VIP is much more active than PACAP-38 in eliciting both aldosterone and corticosterone response, which appears to be in contrast with its higher affinity for $\mathrm{VPAC}_{1}$ than $\mathrm{PAC}_{1}$ receptors. PACAP-27 is much less effective than PACAP38 , despite their binding potency to $\mathrm{PAC}_{1}$ and $\mathrm{VPAC}_{2}$ is similar. Perhaps, the reported occurrence of two types of $\mathrm{PAC}_{1}$ receptors, which possess similar affinity for both PACAPs (type A) and higher affinity for PACAP-38 than PACAP-27 (type B) $(27,28)$, could explain this last finding. In fact, it could be hypothesized that rat adrenocortical cells are mainly provided with $\mathrm{PAC}_{1}$ type $\mathrm{B}$ receptors. All the subtypes of VIP/PACAP receptors have been cloned (for review, see 10), and further molecular-biological studies are needed to elucidate the distribution and the functional role played by VIP/PACAP receptors in the adrenal gland physiology.

Acknowledgements. This work was supported by SCSR grant No. A-P05A-030-13, and performed in the frame of the Polish-Italian Agreement of Scientific and Technical Cooperation.

\section{REFERENCES}

1. Andreis P.G., Malendowicz L.K., Belloni A.S. and Nussdorfer G.G. (1995) Effects of pituitary adenylate-cyclase activating peptide (PACAP) on the rat adrenal secretory activity: preliminary in vitro studies. Life Sci.53, 135-142.

2. Arimura A. (1992) Receptor for pituitary adenylate cyclase-acivating polypeptide: comparison with vasuactive intestinal peptide receptors. Trends Endocrinol. Metab. 3, 288-294.

3. Arimura A. and Shioda S. (1995) Pituitary adenylate cyclase-acivating polypeptide (PACAP) and its receptors: neuroendocrine interactions. Front. Neuroendocrinol. 16, 53-88.

4. Arimura A., Somogyvari-Vigh A., Miyata A., Mizuno K., Coy D.H. and Kitada C. (1991) Tissue distribution of PACAP as determined by RIA: highly abundant in the rat brain and testis. Endocrinology 129, 2787-2789.

5. Bernet F., Bernard J., Laborie C., Montel V., Maubert E. and Dupouy J.P. (1994) Neuropeptide Y (NPY)- and vasoactive intestinal peptide (VIP)-induced aldosterone secretion by rat capsule/glomerulosa zone could be mediated by catecholamines via $\beta_{1}$ adrenergic receptors. Neurosci. Lett. 166, 109-112.

6. Bodart V., Babinski K., Ong H. and De Lean A. (1997) Comparative effect of pituitary adenylate cyclaseactivating polypeptide on aldosterone secretion in normal bovine and human tumorous adrenal cells. Endocrinology 138, 566- 573 .

7. Bornstein S.R., Haidan A. and Ehrhart-Bornstein M. (1996) Cellular communication in the neuroadrenocortical axis: role of vasoactive intestinal polypeptide (VIP). Endocr: Res. 22, 819-829.

8. Dickinson T., Fleetwood-Walker S.M., Mitchell R. and Lutz E.M. (1997) Evidence for roles of vasoactive intestinal polypeptide (VIP) and pituitary adenylate cyclaseactivating polypeptide (PACAP) receptors in modulating the responses of rat dorsal horn neurons to sensory inputs. Neliropeptides 31, 175-185.

9. Haidan A., Hilbers U., Bornstein S.R. and EhrhartBornstein M. (1998) Human adrenocortical NCI-H295 cells express VIP receptors. Steroidogenic effect of vasoactive intestinal peptide (VIP). Peptides 19, 15111517.

10. Harmar A.J., Arimura A., Gozes I., Journot L., Laburthe M., Pisegna J.R., Rawlings S.R., Robberecht P., Said S.I., Sreedharan S.P., Wank S.A. and Waschek J.A. (1998) International Union of Pharmacology. XVIII. Nomenclature of receptors for vasoactive intestinal peptide and pituitary adenylate cyclase-activating polypeptide. Pharmacol. Rev. 50, 265-270.

11. Hinson J.P., Ho M.M., Vinson G.P. and Kapas S. (1996) Vasoactive intestinal peptide is a local regulator of adrenocortical function. Endocr. Res. 22, 831-838.

12. Hinson J.P., Kapas S., Orford C.D. and Vinson G.P. (1992) Vasoactive instestinal peptide stimulation of aldosterone secretion by the rat adrenal cortex may be mediated by the local release of catecholamines. J. Endocrinol. 133, 253-258.

13. Lee C.Y., Mcpherson M., Licko V. and Ramachandran J. (1980) Pituitary corticotropin-inhibitory peptide: properties and use in study of corticotropin action. Arch. Biochem. Biophys. 201, 411-419.

14. Li Z.G., Queen G. and La Bella F.S. (1990) Adrenocorticotropin, vasoactive intestinal polypeptide, growth hormone-releasing factor, and dynorphin compete for common receptors in brain and adrenal. Endocrinology 126, 1327-1333.

15. Lightly E.R.T., Walker S.W., Bird I.M. and Williams B.C. (1990) Subclassification of $\beta$-adrenoceptors responsible for steroidogenesis in primary cultures of bovine 
adrenocortical zona fasciculata/reticularis cells. $\mathrm{Br} . \mathrm{J}$. Pharmacol. 99, 709-712.

16. Malendowicz L.K., Nussdorfer G.G., Markowska A., Nowak K.W. and Torlinski L. (1993) Effect of neuromedin- $\mathrm{N}$ on the pituitary-adrenocortical axis of dexamethasone-suppressed rats. Netropeptides 24, 1-4.

17. Malendowicz L.K., Rebuffat P., Nussdorfer G.G. and Nowak K.W. (1998) corticotropin-inhibiting peptide enhances aldosterone secretion by dispersed rat zona glomerulosa cells. J. Steroid Biochem. Mol. Biol. 67, 149152.

18. Mazzocchi G., Malendowicz L.K., Meneghelli V., Gottardo G. and Nussdorfer G.G. (1993) Vasoactive intestinal polypeptide (VIP) stimulates hormonal secretion of the rat adrenal cortex in vitro: evidence that adrenal chromaffin cells are involved in the mediation of the mineralocorticoid but not glucocorticoid secretagogue action of VIP. Biomedical Res. 14, 435-440.

19. Mazzocchi G., Malendowicz L.K. and Nussdorfer G.G. (1994) Stimulatory effect of vasoactive intestinal peptide (VIP) on the secretory activity of dispersed rat adrenocortical cells. Evidence for the interaction of VIP with ACTH receptors. J. Steroid Biochem. Mol. Biol. 48, 507-510.

20. Mazzocchi G., Rebuffat P., Gottardo L. and Nussdorfer G. G. (1998) Vasoactive intestinal peptide stimulates rat adrenal glucocorticoid secretion, through an ACTH receptor-dependent activation of the adenylate cyclasedependent pathway. Horm. Metab. Res. 30, 241-243.

21. Neri G., Andreis P.G., Prayer-Galetti T., Rossi G.P., Malendowicz L.K. and Nussdorfer G.G. (1996) Pituitary adenylate cyclase-activating peptide enhances aldosterone secretion of human adrenal gland: evidence for an indirect mechanism, probably involving the local release of catecholamines. J. Clin. Endocrinol. Metab. 81, 169-173.

22. Neri G., Malendowicz L.K., Andreis P.G. and Nussdorfer G.G. (1993) Thyrotropin-releasing hormone inhibits glucocorticoid secretion of rat adrenal cortex: in vivo and in vitro studies. Endocrinology 133, 511-514.

23. Nussdorfer G.G. (1996) Paracrine control of adrenal cortical function by medullary chromaffin cells. Pharmacol. Rev. 48, 495-530.

24. Nussdorfer G.G. and Malendowicz L.K. (1998) Role of VIP, PACAP, and related peptides in the regulation of the hypothalamo-pituitary-adrenal axis. Peptides 19, 14431467.

25. Rawlings S.R. and Hezareh M. (1996) Pituitary adenylate cyclase-activating polypeptide (PACAP) and PACAP/ vasoactive intestinal polypeptide receptors: actions on the anterior pituitary gland. Endocr. Rev. 17, 4-29.

26. Robberecht P., Gourlet P., De Neef P., Woussen-Colle M. C., Vandermeers-Piret M.C., Vandermeers A. and Christophe J. (1992) Receptor occupancy and adenylate cyclase activation in AR 4-2J rat pancreatic acinar cell membranes by analogs of pituitary adenylate cyclase-activating peptides amino-terminally shortened or modified at position 1, 2, 3, 20, or 21. Mol. Pharmacol. 42, 347-355.

27. Robberecht P., Woussen-Colle M.C., De Neef P., Gourlet P., Buscail L., Vandermeers A., Vandermeers-Piret M.C. and Christophe J. (1991) The two forms of the pituitary adenylate cyclase-activating polypeptide [PACAP (1-27) and PACAP $(1-38)]$ interact with distinct receptors on rat pancreatic AR4-2J cell membranes. FEBS Lett. 286, 133136.

28. Shivers B.D., Gorcs T.J., Gottschall P.E. and Arimura A. (1991) Two high affinity binding sites for pituitary adenylate cyclase-activating polypeptide have different tissue distributions. Endocrinology 128, 3055-3065.

29. Xu X.J. and Wiesenfeld-Hallin Z. (1991) An analogue of growth hormone releasing factor (GRF), (Ac-Try', DPhe ${ }^{2}$-GR F-(1-29), specifically antagonizes the facilitation of the flexor reflex induced by intrathecal vasoactive intestinal peptide in rat spinal cord. Neuropeptides 18, 129-135. 